\title{
Poisoning in children and adolescents notified at a toxicology center in the Northeast of Brazil
}

Maria Lucineide Porto Amorim 1

Maria Júlia Gonçalves de Mello 2

Marília Teixeira de Siqueira 3

\footnotetext{
Secretaria de Saúde de Pernambuco. Rua Dona Maria Augusta Nogueira, 519. Bongi. Recife, PE, Brasil. CEP: 50751-530.

E-mail: lucineideporto@uol.com.br

2 Instituto de Medicina Integral Prof. Fernando Figueira. Recife, PE, Brasil.

3 Faculdade de Ciências Médicas-Universidade de Pernambuco. Recife, PE, Brasil.
}

\begin{abstract}
Objective: to analyze the clinical and epidemiological profile of poisoning in children and adolescents under 12years old.

Methods: a cross-sectional study with analytical component based on poisoning notifications at the Centro de Toxicologia de Pernambuco (Toxicological Center in Pernambuco), carried out in 2012 and 2014. Allergic reactions and contaminated food poisoning were excluded. Sociodemographic characteristics, type of toxic agent, circumstance, place of occurrence, time until care and patients' evolution were analyzed. The distribution of frequencies and associations among the variables through prevalence ratio and the chi-squared test was determined.

Results: Among 2,843 patients registered, 1,601 (56.3\%) were poisoned by chemical substances and 1,242 (43.7\%) by poisonous animals. Most lived in urban areas (90.6\%) and were attended for care after an hour of the incident (47.6\%). The poisoning frequency of chemical substances was higher among children under five years old $(P R=2.34 ; C I 95 \%=$ 2.14-2.56) and there was no difference in the sexes $(P R=1.00 ; C I 95 \%=0.94-1.07)$. The predominant medicine (45.0\%) for poisoning was between chemical substance and scorpions (77.0\%). Poisoning occurred as accidental in $92.2 \%$ and $99.6 \%$ of chemical substance occurred at home. There were six deaths by chemical intake and two by scorpions.

Conclusions: poisoning in Pernambuco State is considered a public health issue given by its frequency and it occurred mostly with children under 5 years old accidentally and at home. Key words Poisoning, Bites and stings, Accidents, Children, Adolescent
\end{abstract}




\section{Introduction}

Intoxication, also called poisoning, is a global health problem and responsible for millions of calls made for the information and toxicological assistance centers for children and adolescents worldwide.1,2 In 2004, there were approximately 350 thousand deaths by poisoning throughout the world, in which approximately $45,000(13.0 \%)$ were under 20 years old. ${ }^{2}$ In 2007, the World Health Organization (WHO) included accidental poisoning with poisonous animals in the neglected disease group. ${ }^{3}$

Registration on poisoning in children and adolescents has been increasing progressively in Brazil. In 2010 and 2014, the Sistema de Informação de Agravos de Notificação (SINAN) (National Injury Notification System) registered 16,183 and 24,521 cases of poisoning in children under 14 years old, respectively. ${ }^{4}$ It should be emphasized that in these five years, there was an increase of $52.2 \%$ of notifications mainly due to chemical poisoning $(98.0 \%)$ when comparing to the increase of poisoning by poisonous animals $(20.0 \%) .{ }^{4}$ The medicine constitute in the main group of chemical substances involved in poisonings $(40.0 \%)$, followed by household products $(14.0 \%)$. Among poisonous animals, scorpions were responsible for $46.6 \%$ of the cases. 4 In Pernambuco State, in the same period of 2010 to 2014, the Centro de Assistência Toxicológica (CEATOX) (Toxicological Assistance Center) has doubled the number of notifications from 2,316 to 4,585.4

The Centros de Informações e Assistência Toxicológica (CIATs) (Information and Toxicological Assistance Centers) in Brazil, are health services responsible for providing toxicological information to the population in general and the health professionals, directing immediate conduct, diagnosis and treatment for the exposed and/or poisoned people, aiming to reduce morbimortality. In the 1970's the public health managers in São Paulo State created the first specialized service in toxicology. 5 The CIATs gradually became a reference in clinical toxicology in the Sistema Unico de Saúde (SUS) (Public Health System), with permanent shift care by tele-consulting or face to face and that began to be part of the Rede de Atenção às Urgências e Emergências (RUE) (Urgencies and Emergencies Care Network), according to the Ministério da Saúde (MS) (Ministry of Health) recommendation of 2015 Decree Number 1,678.6 Currently, Brazil counts on 30 CIATs, however, researches on epidemiological data of these centers are still scarce.
Based on the premise that the access to accurate and reliable information is important in the formulation of public policies, this study analyzes data from acute poisoning in children and adolescents up to 12 years old, notified at a reference center in toxicology in the Northeast of Brazil.

\section{Methods}

A cross-sectional study with analytical component and secondary data on poisoning notified at the Centro de Assistência Toxicológica de Pernambuco (CEATOX/PE) (Toxicological Assistance Center in Pernambuco) during the period of January 2012 to December 2014. The CEATOX/PE is a reference state care service for cases of poisoning by chemical substances and poisonous animals. In this period, there were 31,641 calls, in which 7,435 (23.5\%) were confirmed cases of poisoning, 13,983 (44.2\%) were for information requests, and 10,223 (32.3\%) were for active searches on revaluations.

In this study were included notifications of acute poisoning involving children and adolescents up to 12 years of age and excluded the adverse and allergic reactions in the use of drugs and food poisoning caused by infectious agents.

This study was approved by the Comitê de Ética em Pesquisa em Seres Humanos (CEP) (Ethics Committee in Human Research) at the Hospital Complex of the Hospital Universitário Oswaldo Cruz-HUOC/PROCAPE (Oswaldo Cruz Hospital University) (Decree Number 896,663).

The notification tool at the service is the files on exogenous poisoning investigation and accidents caused by poisonous animals at SINAN.7 The analyzed variables were: age (later categorized into two age groups: less than 5 years old and greater than or equal to 5), sex, residence, residential area (urban or rural), time between care at the health service (1 hour was considered as a cut-off point), toxic agent group, circumstance (the main reason for the origin of the injury), place of exposure (accidentally or at home) and clinical evolution to death. The residence was classified according to the Gerência Regional de Saúde (GERES) (Regional Health Management) which are the 12 administrative units of the Secretaria de Saúde do Estado de Pernambuco (Health Secretary of Pernambuco State), which joins 184 towns and the territory of Fernando de Noronha Island.

In cases of poisoning by poisonous animal sting, the severity (mild, moderate and severe, according to the MS's criteria) were evaluated, 8 the use of specific anti-poison serotherapy and the evolution to 
death.

The data analysis was carried out by using EpiInfo program, version 3.5.4. It was determined the distribution of absolute and relative frequencies, central tendency measurements and dispersion of the variables studied. The association of the event with the independent variables was analyzed by calculating the prevalence ratios (PR) and by the association of the chi-square test, adopting a significance level of 0.05 .

\section{Results}

A total of 2,843 notifications of poisoning in children and adolescents up to 12 years old, 1,601 $(56.3 \%)$ were poisoning by chemical substances and $1,242(43.7 \%)$ by poisonous animals. These notifications were mainly from residents of towns that composes of the Metropolitan Region of Recife (78.9\%) (Figure 1). The median age of cases in poisoning by chemical substances was two years old [interquartile range (IQR) from 1 to 4 years old] and the cases of poisonous animals was 5.5 years (IQR of 2.5 to 9.0 years old).

The sociodemographic characteristics of the study population are presented in Table 1. Poisoning predominated children under the age of five $(60.2 \%)$ and mostly occurred in residents in the urban area $(90.6 \%)$. In relation to the elapsed time between the exposure and care at the health service, $47.7 \%$ of the patients arrived at the health unit after the first hour; patients poisoned by poisonous animals were treated with higher frequency in the first hour when compared to the ones poisoned by chemical substances $(\mathrm{PR}=1.15 ; \mathrm{CI} 95 \%=1.07-1.24 ; p<0.001)$.

Poisoning by chemical substances in children under five years of age were 2.34 times more prevalent when compared to those in the age range between 5 and 12 years old ( $\mathrm{PR}=2.34$; CI95\% $=2.14$ $-2,56 ; p<0,001)$. There was no difference between the sexes. The poisoning by chemical substances were more prevalent in the urban area $(\mathrm{PR}=1.36$; CI95\% $=1,17-1,58 ; p<0.001)$.

In Table 2, the type of agent was highlight by age group. In all age groups, medication was the main agents, responsible for $45.0 \%$ of poisoning by chemical substances. Among the medication, psychotropic drugs were the most notified (17.0\%), followed by analgesics (5.8\%) and appetite stimulants $(3.1 \%)$. After the medications, next is poisoning by chemical products $(30.5 \%)$ and in this group, the most notified product was bleach (70.8\%) followed by chlorine and kerosene, both with $8.0 \%$. There were 179 cases of poisoning by pesticides; of these, $65(36.3 \%)$ were attributed to a pesticide called "chumbinho" (rat poison) that corresponded to $4.0 \%$ of the total number of poisoning by chemical substances.




Distribution of sociodemographic characteristics in children under 12 years old by poisoning. CEATOX-PE. 2012 to 2014.

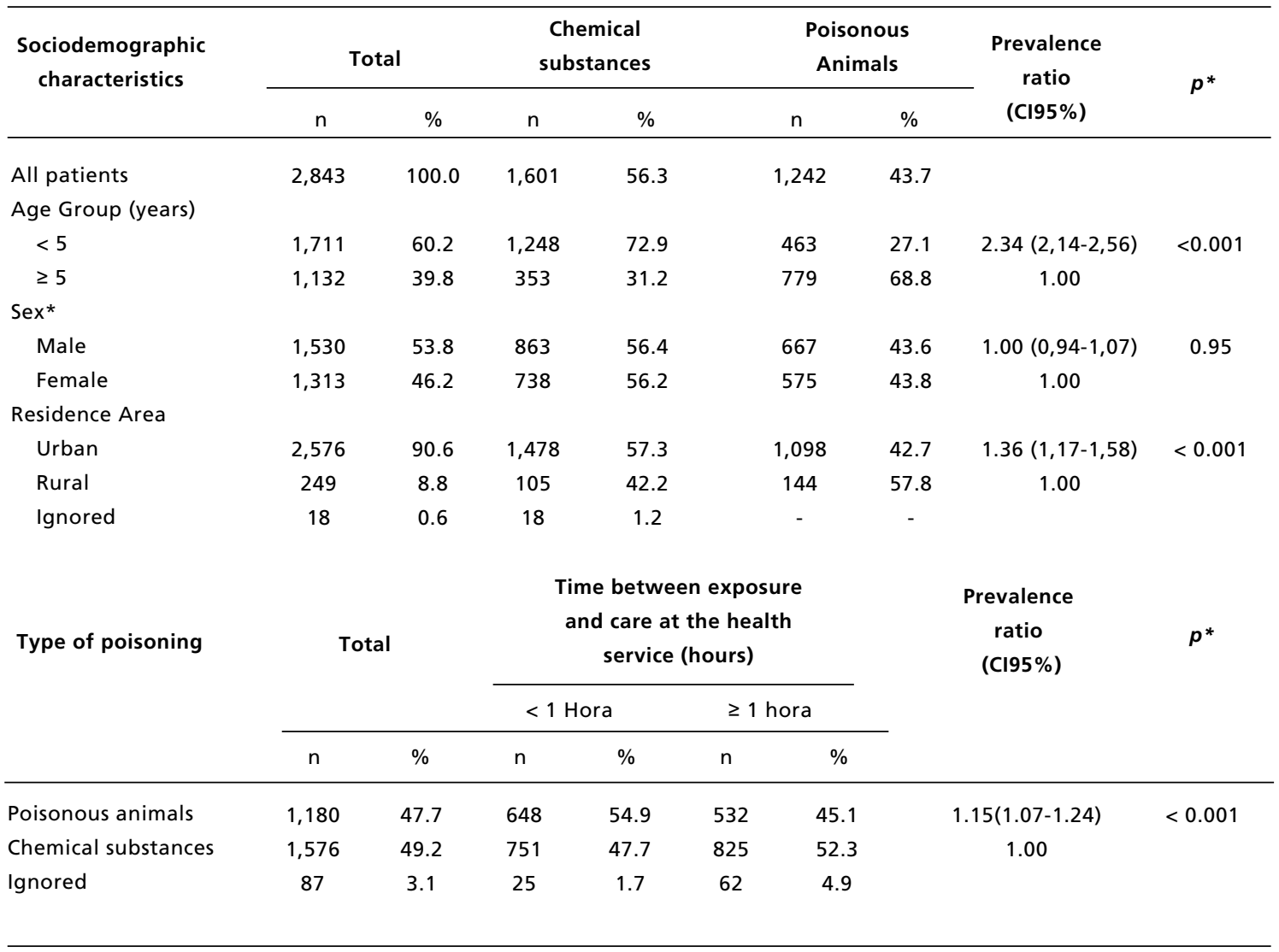

Source: CEATOX/Directors of Integral Assistance in Health (DGAIS) / Executive Secretary in Health Care (SEAS) / State Health Department in Pernambuco (SES-PE). 
Distribution of food poisoning in children under 12 years old, according to the toxic agent group and age group. CEATOXPE. 2012 to 2014.

\begin{tabular}{|c|c|c|c|c|c|c|}
\hline \multirow{3}{*}{$\begin{array}{c}\text { Toxic agent } \\
\text { group }\end{array}$} & & & \multicolumn{4}{|c|}{ Age group } \\
\hline & \multicolumn{2}{|c|}{ Total } & \multicolumn{2}{|c|}{$<5$ years old } & \multicolumn{2}{|c|}{5 to 12 years old } \\
\hline & $\mathrm{n}$ & $\%$ & $\mathrm{n}$ & $\%$ & $\mathrm{n}$ & $\%$ \\
\hline Chemical substances & 1,601 & 56.3 & 1,248 & 78.0 & 353 & 22.0 \\
\hline Medication & 721 & 45.0 & 516 & 41.3 & 205 & 58.1 \\
\hline Chemical product & 488 & 30.5 & 428 & 34.3 & 60 & 17.0 \\
\hline Pesticide & 179 & 11.1 & 128 & 10.2 & 51 & 14.4 \\
\hline Rat Poison & 53 & 3.3 & 47 & 3.8 & 6 & 1.7 \\
\hline Cosmetic / hygiene & 43 & 2.7 & 41 & 3.3 & 2 & 0.6 \\
\hline Veterinary product & 39 & 2.4 & 36 & 2.9 & 3 & 0.8 \\
\hline Toxic plant & 31 & 1.9 & 23 & 1.8 & 8 & 2.3 \\
\hline Others* or ignored & 47 & 2.9 & 29 & 2.4 & 18 & 5.1 \\
\hline Poisonous animals & 1,242 & 43.7 & 463 & 37.3 & 779 & 62.7 \\
\hline Scropion & 957 & 77.0 & 374 & 80.8 & 583 & 74.8 \\
\hline Serpent & 153 & 12.3 & 40 & 8.6 & 113 & 14.5 \\
\hline Other animals** & 116 & 9.3 & 43 & 9.3 & 73 & 9.4 \\
\hline Ignored & 16 & 1.3 & 6 & 1.3 & 10 & 1.3 \\
\hline
\end{tabular}

Source: CEATOX / Directors of Integral Assistance in Health (DGAIS) / Executive Secretary in Health Care (SEAS) / State Health Department in Pernambuco (SES-PE)

* Other drugs: metal, abuse drug, use of household product, cosmetic/personal hygiene

**Other poisonous animals: spiders, bees, caterpillars.

Table 3

Distribution of poisoning by poisonous animals in children under 12 years of age, according to the severity, the use of specific anti-poison serotherapy and the evolution to death. CEATOX-PE. 2012 to 2014.

\begin{tabular}{|c|c|c|c|c|c|c|}
\hline \multirow[t]{2}{*}{$\begin{array}{c}\text { Severity } \\
\text { classification }\end{array}$} & \multicolumn{2}{|c|}{ Total } & \multicolumn{2}{|c|}{$\begin{array}{l}\text { The use of } \\
\text { serotherapy }\end{array}$} & \multicolumn{2}{|c|}{ Death } \\
\hline & $\mathrm{n}$ & $\%$ & $\mathrm{n}$ & $\%$ & $\mathrm{n}$ & $\%$ \\
\hline Mild & 1,107 & 89.1 & 31 & 2.8 & 0 & - \\
\hline Moderate & 79 & 6.4 & 61 & 77.2 & 0 & - \\
\hline Severe & 56 & 4.5 & 56 & 100.0 & 2 & 3.6 \\
\hline Total & 1,242 & 100.0 & 148 & 11.9 & 2 & 0.2 \\
\hline
\end{tabular}

Source: CEATOX/ Directors of Integral Assistance in Health (DGAIS) / Executive Secretary in Health Care (SEAS) / State Health Department in Pernambuco (SES-PE). 
Figure 2

Distribution of circumstances and place of exposure of children under 12 years of age by poisoning. CEATOX-PE, 2012 to 2014.

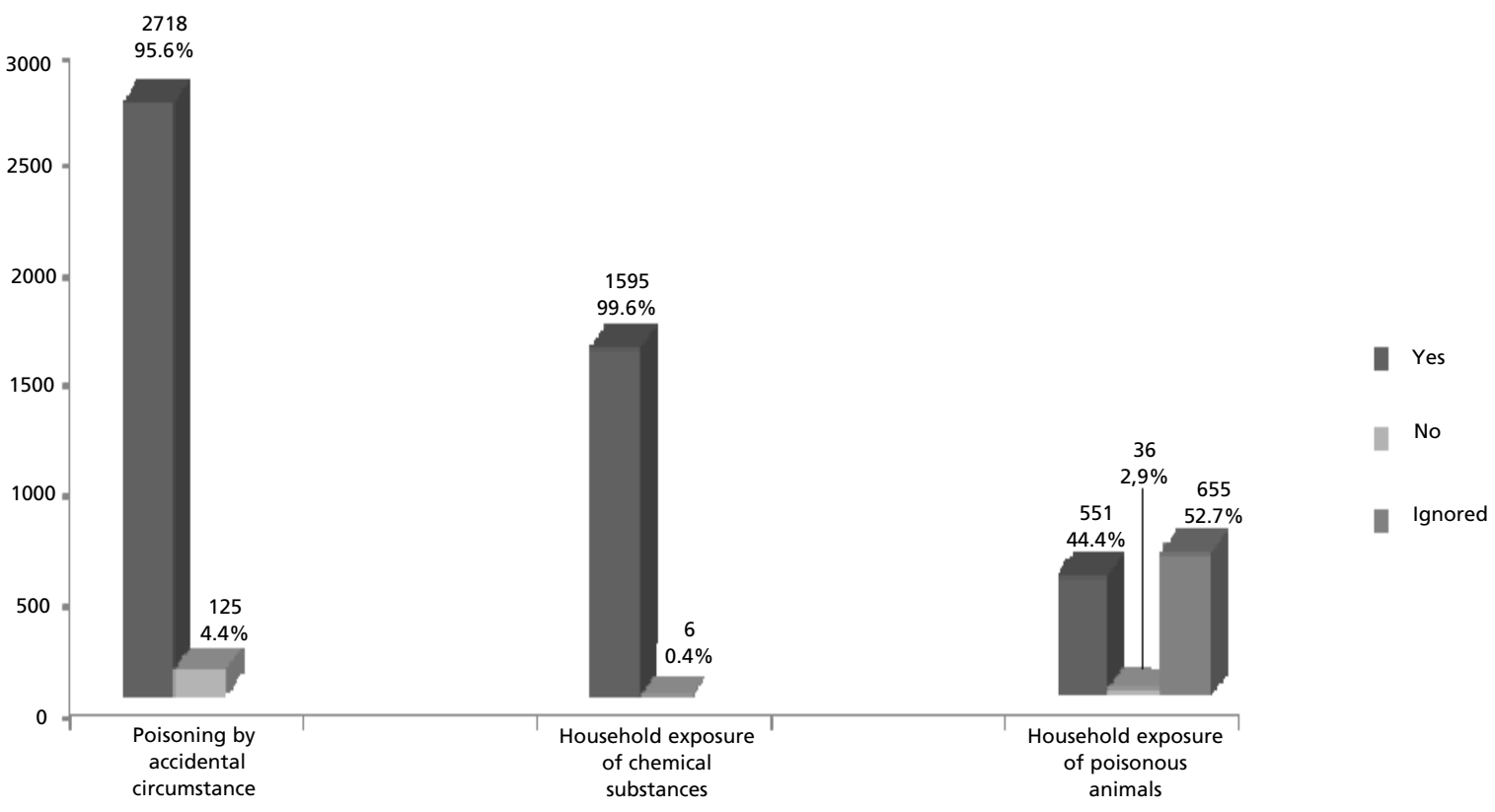

Among the 1,242 cases of accidents caused by poisonous animals, $957(77.0 \%)$ were by scorpions and $153(12.3 \%)$ by serpents. Table 3 shows that most of the cases were classified as mild accidents $(89.1 \%)$ and $148(11.9 \%)$ patients used specific antipoison serotherapy.

Figure 2 demonstrates that the poisoning were unintentional (accidentally) in $95.6 \%$ of the cases. The residence area was the location of $99.6 \%$ of occurrence in cases of poisoning by chemical substances intake and in $44.4 \%$ were by poisonous animals.

In the study period there were eight deaths $(0.3 \%)$, six by chemical substances intake (four per agricultural pesticide called "chumbinho" (rat poison) and two cases by industrial chemical, benzene and gasoline) and two other by a scorpion, the Tityus stigmurus species.

\section{Discussion}

Among the unintentional injuries, poisoning is a public health problem throughout the world for its high frequency and morbidity. 1,2 The results of this study highlight the importance of these injuries in children and adolescents up to 12 years of age in Pernambuco.

This study found that these injuries were more prevalent in the group of children under the age of five, this profile was also observed in other regions in Brazil ${ }^{9-11}$ and the world.1,2 At this age group, children are more vulnerable to poisoning and deserve greater attention, which can be explained by inherent factors in the child's development. The curiosity and the exploration of the environment make children more exposed and they take substances and objects to the mouth. 12 Studies indicate that the reduction or elimination of the risk factors, such as the lack of caregivers' supervision and the improper storage of chemical products (in a height less than $150 \mathrm{~cm}$ ), perhaps reduces about 13 to $19 \%$ of these childhood events, respectively. 12,13

According to WHO report ${ }^{2}$ effective interventions in reducing poisoning should involve, in addition to the exclusion of toxic substances, broader strategies that encompasses the legal obligation of adopting embalagens especiais para crianças (EEPC) (seal proof packages for children) and packaging and marketing with non-lethal doses. ${ }^{2,14}$ Also according to this report, the use of keys in cabinets and drawers are effective practices for prevention. There is no sufficient scientific evidence proving that guidance to parents/children and actions of good matters at home reduce poisoning in childhood.

We did not observe the differences in relation to sex in our study, which differs from national and international researches, $1,9,15$ which describe poisoning mostly in boys. This finding may explain 
the high number of poisoning in our midst which has occurred in small children and at home. The limited physical space of mobility did not allow to establish differences of the high exposure of events between boys in relation to girls.

Even from the urban area, only half of these patients arrived at the health service in less than an hour after the event, time considered to be able to perform an effective gastric decontamination. 16 This fact may suggest that the population had difficulty to access the health services or it is not sufficiently clear about the potential risks in poisoning.

Among the agents involved, the results were similar to other studies $2,9-11,15,17,18$ that mention medications as the most common agents found in the notifications of food poisoning by toxic substances. However, this information differs from SINAN, which registers food and beverages among the main toxic agents in Brazil with approximately $10.0 \%$ of the notifications. 4 We understand that food and drinks were contaminated by a toxic agent and should not be notified as etiological agents.

Still in relation to toxic substance, we emphasize in our midst, poisoning by agricultural pesticides which is sold illegally as rat poison called "chumbinho" of high lethality, is responsible for half of the deaths registered. According to a research published in 2009, a similar problem occurred in Rio de Janeiro State, as $10.0 \%$ of the poisoning in children under six years of age were attributed to rat poison.

The research showed that poisoning by scorpions was the main reason to call CEATOX. The occurrence of these accidents in urban areas may be explained by the high demographic density, disorderly growth and accumulation of garbage favoring the proliferation of cockroaches, the scorpion's main food. 8,19

During the interval of the research, a low percentage of cases requiring specific anti-poison serotherapy were observed. This reflects a characteristic of the species most commonly found in the Northeast region, the Tityus stigmurus scorpion, whose poison usually causes mild clinical manifestations, not justifying the use of a specific antipoison serotherapy.

Despite the high prevalence of this injury in children, ${ }^{4}$ continuous educational programs with information for the health professionals and for the popu- lation in risky areas associated to the availability of anti-poison serotherapy decentralized throughout Pernambuco State, there has been no death registrations by this cause in this State since 2013 .

As a limitation in this study, we emphasize that the data were from the only Centro de Informação Toxicológica (Toxicological Information Center) where notification is spontaneous, but did not represent the totality of cases. It is estimated that approximately $25.0 \%$ of the cases of poisoning in children under six years of age was not notified at the Centros de Informações Toxicológicas (Toxicological Information Centers), due to the lack of injury severity contributing to distort the magnitude of the problem. ${ }^{1}$

According to the review of the issue and the results of this study, we propose the following suggestions and recommendations: strengthen the CIATs with financial resources to develop its full potential of actions in surveillance and assistance; mobilize the organized society, mainly the Pediatrics Society to develop campaigns along with health professionals, educators and the population, aiming to prevent these injuries; articulate with the Secretary of Education to insert themes related to prevent childhood accidents in the school context involving educators; stimulate a debate with the managers of universities and technical courses to include toxicology to be taught in the health area, aiming the formation of professionals who act in preventing, diagnosing and treating these injuries; to act on the approval of law projects linked to prevent accidents with children at the Brazilian National Congress, suggesting that children medications are packaged in seal proof lids, preventing children to open easily.

Finally, we suggest a more adequate planning strategy to control and prevent accidents caused by poisonous animals focusing on scorpions, as well as combating illegal practice of trade of pesticides for other purposes, especially rat poison.

We conclude that poisoning in Pernambuco is a public health problem by its frequency and morbidity. Poisoning occurs mainly in children under five years of age accidentally (unintentional) and at home. Based on epidemiological data described it is necessary to establish educational measurements associated to laws aiming to prevent these injuries. 


\section{References}

1. Mowry JB, Spyker DA, Cantilena Jr LR, McMillan N, Ford M. ol Centers' National Poison Data System 2013 Annual Report of the American Association of Poison Contr(NPDS): 31st Annual Report. Clin Toxicol. 2014; 52: 1032-283.

2. World Health Organization - WHO. World report on child injury prevention. Peden M, Oyegbite K, Ozanne-Smith J, Hyder AA, Branche C, Rahman AF, Rivara F. and Bartolomeos K. Geneve; 2008. 233 p.

3. World Health Organization - WHO. Rabies and envenom ings: a neglected public health issue: report of a Consultative Meeting. World Health Organization, editor. Who. Geneve; 2007.5 - 12 p.

4. Brasil. Ministério da Saúde. Secretaria de Vigilância em Saúde. Sistema de Informação de Agravos de Notificação. Intoxicação exógena e acidente por animais peçonhentos [Internet]. [cited 2016 May 16]. Available from: http://tabnet.datasus.gov.br/cgi/deftohtm.exe?sinannet/cnv/ Intoxbr.def

5. Azevedo JLS. A Importância dos Centros de Informação e Assistência Toxicológica e sua Contribuição na Minimização dos Agravos à Saúde e ao Meio Ambiente no Brasil. [Brasilia]: Universidade de Brasília; 2006.

6. Brasil. Ministério da Saúde. Portaria No 1.678, de 2 de outubro de 2015. Diario Oficial da União Brasíia: Imprensa Nacional; 2015 p. 55.

7. Laguardia J, Domingues CMA, Carvalho C, Lauerman CR, Macário E, Glatt R. Sistema de informação de agravos de notificação em saúde (Sinan): desafios no desenvolvimento de um sistema de informação em saúde. Epidemiol Serv Saude. 2004; 13(3): 135-46.

8. Brasil. Ministério da Saúde. Fundação Nacional de Saúde. Manual de Diagnóstico e Tratamento de Acidentes por Animais Peçonhentos. 2 ed. Assessoria de Comunicação e Educação em Saúde/Ascon/Pre/FUNASA, editor. Brasíia; 2001. $120 \mathrm{p}$

9. Domingos SM, Borghesan NBA, Merino $M$ de FGL, Higarashi IH. Internações por intoxicação de crianças de zero a 14 anos em hospital de ensino no Sul do Brasil, 2006-2011. Epidemiol Serv Saúde. 2016; 25(2): 343-50.

10. Werneck GL, Hasselmann MH. Intoxicações exógenas em crianças menores de seis anos atendidas em hospitais da região metropolitana do Rio de Janeiro. Rev Assoc Med
Bras. 2009; 55(3): 302-7.

11. Oliveira F Suchara E. Perfil epidemiológico das intoxicações exógenas em crianças e adolescentes em município do Mato Grosso. Rev Paul Pediatr. 2014; 32 (4): 299-305.

12. Hahn $\mathrm{R}$ da $\mathrm{C}$, Labegalin MPC, Oliveira MLF. Características de intoxicações agudas em crianças: estudo em um centro de assistência toxicológica. 2013; 4: 18-22.

13. Ramos CLJ, Barros HMT, Stein AT, Costa JSD. Fatores de risco que contribuem para o envenenamento pediátrico. J Pediatr (Rio J). 2010; 86 (5): 435-40.

14. Wynn PM, Zou K, Young B, Majsak-newman G, Hawkins A, Kay B, Mhizha-Murira J, Kendrick D. Prevention of childhood poisoning in the home : overview of systematic reviews and a systematic review of primary studies. Int J Inj Contr Saf Promot. 2015; 23 (1): 3-28.

15. Holder Y, Matzopoulos R, Smith N. Poisons in: World report on child injury prevention World Health Organization - WHO. World report on child injury prevention. Peden M, Oyegbite K, Ozanne-Smith J, Hyder AA, Branche C, Rahman AF, Rivara F. and Bartolomeos K. Geneve; 2008. 123- 42.

16. Bucaretchi F, Baracat ECE. Exposições tóxicas agudas em crianças : um panorama. J Pediatr (Rio J). 2005; 81(Supl. 5): S212-22.

17. Ramos CLJ, Targa MBM, Stein AT. Perfil das intoxicações na infância atendidas pelo Centro de Informação Toxicológica do Rio Grande do Sul (CIT/RS), Brasil. Cad Saúde Pública. 2005; 21(4): 1134-41.

18. Pérez DA, Gallardo ÁJL, Castro YF, Romeu SE, Abreu CM. Lesiones no intencionales por intoxicación en Pediatría. Unintentional injuries by poisoning in Pediatrics. Mediciego. 2012; 18(Supl. 2). Disponível em: http://bvs.sld.cu/revistas/mciego/vol18_supl2_2012/pdf/ T8.pdf

19. Guerra CMN, Carvalho LFA, Colosimo EA, Freire HBM. Análise de variáveis relacionadas á evolução letal do escorpionismo em crianças e adolescentes no estado de Minas Gerais no período de 2001 a 2005. J Pediatr (Rio J). 2008; 84(6): 509-15.

Received on March 14, de 2017

Final version presented on August 1, 2017

Approved on November 10, 2017 